\title{
Studi Pengaruh Penambahan Tanah Lempung Terhadap Daya Dukung Pasir Pantai
}

\author{
Herman $^{1}$, Fiska ${ }^{2}$ \\ Dosen Program Studi Sarjana Teknik Sipil ${ }^{1}$, Fakultas TeknikMahasiswa Program Studi Sarjana \\ Teknik Sipil, Fakultas Teknik ${ }^{2}$ \\ Institut Teknologi Padang \\ DOI: http://dx.doi.org/10.31869/rtj.v3i2.1840
}

\begin{abstract}
Abstrak: Pasir pantai keberadaannya sangat berlimpah diwilayah Indonesia, hal itu dikarenakan Indonesia terdiri dari pulau-pulau dengan daerah pantai yang sangat luas. Terbentuk akibat pengikisan batuan dari erosi gelombang laut, memiliki tekstur yang halus dan relatif bulat dengan ukuran butir berkisar antara 0,55 - 2,50 $\mathrm{mm}$. Kelemahan tanah pasir ini antara lain, memiliki gradasi butiran seragam, kekuatan geser yang rendah, memiliki daya lekat yang cenderung lemah dan sulit untuk dipadatkan dan mempertahankan kepadatannya karena gampang terhambur akibat beban terutama beban bergerak. Untuk memperbaiki kelemahan-kelemahan tanah pasir pantai tersebut, digunakan tanah lempung. Pasir pantai sebagai sampel diambil dari Pasir Jambak Tabing Padang, tanah lempung sebagai bahan pencampur adalah tanah lempung dari Palapa Batang Anai Pariaman. Komposisi campuran lempung terhadap pasir pantai adalah $0 \%, 15 \%, 30 \%$ dan $45 \%$ terhadap berat kering pasir pantai. Pengujian yang dilakukan terdiri dari uji sifat fisis meliputi uji specific gravity $(G s)$, batas cair $(L L)$, uji saringan dan hidrometer, sedangkan uji sifat mekanis yang terdiri dari uji pemadatan dan uji CBR laboratorium (soaked, unsoaked). Hasil pengujian menunjukan semakin tinggi persentase tanah lempung didalam kandungan pasir nilai batas cair $(L L)$, persentase lolos saringan no. 200, kadar air optimum, persen pengembangan meningkat, sedangkan nilai-nilai kepadatan tanah, $C B R$ laboratorium (soaked, unsoaked) pada awalnya terjadi peningkatan, seiring dengan bertambahnya jumlah kandungan tanah lempung didalam pasir pantai, nilai-nilai ini cenderung menurun. Hasil terbaik diperoleh dari penelitian ini pada persentase 30\% tanah lempung didalam kandungan pasir pantai.
\end{abstract}

Kata - kata kunci : tekstur,gradasi, fisis, mekanis, persentase

\section{PENDAHULUAN}

Pasir pantai keberadaannya sangat berlimpah diwilayah Indonesia, hal itu dikarenakan Indonesia terdiri dari pulau-pulau dengan daerah pantai yang cukup luas, terbentuk akibat pengikisan batu yang disebabkan erosi gelombang laut, memiliki tekstur yang halus dan bulat dengan ukuran butir berkisar antara $0,55-2,50 \mathrm{~mm}$. Kelemahan tanah pasir ini antara lain, memiliki gradasi butiran seragam, kekuatan geser yang rendah karena memiliki daya lekat yang cenderung lemah dan juga sulit untuk dipadatkan dan mempertahankan kepadatannya karena gampang terhambur kembali jika dibebani terutama beban bergerak, disamping itu pasir pantai memiliki kandungan sulfat dan garam-garam klorida yang sangat tinggi. Pasir pantai dapat menjadi alternatif lain sebagai komponen pencampuran beton apabila terdapat keterbatasan agregat halus. Penggunaan pasir pantai sebagai material bangunan biasa ditemukan didaerah yang tidak memiliki pasir sungai atau keberadaan pasir sungai yang terbatas dan sulit diperoleh. Penggunaan pasir pantai ini tentu saja sudah melalui proses perbaikan dengan mereduksi kandungan garam yang ada didalamnya. Disamping untuk campuran beton, pasir pantai juga digunakan untuk pekerjaan plesteran, pembuatan bata ringan, campuran aspal dan lain-lain. Sebagai tanah dasar jalan (sub grade), pasir pantai tentu kurang tepat penggunaannya, hal itu didasarkan kelemahan-kelemahan pasir pantai seperti yang tersebut diatas, kelemahan itu cukup mendasar bagi tanah yang akan dijadikan tanah dasar (sub grade) jalan. Untuk memperbaiki kelemahan-kelemahan tanah pasir pantai tersebut, penulis mencoba mencampurkan tanah lempung kedalam pasir pantai. Dengan harapan agar hasil yang diperoleh dari penelitian ini dapat memberikan informasi yang baik tentang pemanfaatan pasir pantai sebagai tanah dasar (sub grade) jalan raya, mengingat banyak jalur jalan raya yang keberadaannya memanjang sejajar dengan 
pesisir pantai yang sudah tentu tanah dasarnya tak lepas dari keberadaan pasir pantai. Pada penelitian ini persentase tanah lempung yang dicampurkan kedalam tanah pasir pantai adalah $0 \%, 15 \%, 30 \%$ dan $45 \%$ dari berat kering pasir pantai.

\section{STUDI LITERATUR}

Penambahan pasir pantai terhadap tanah lempung dapat meningkatkan nilai $C B R$ tanah lempung (Muhammad RA. Simanjuntak $d k k$, 2017), sedangkan pasir dari Batang Latang Lubuk Tarok dapat meningkatkan kepadatan, nilai CBR (soaked, unsoaked), nilai kuat tekan bebas dari tanah lempung (Herman,dkk, 2019). Hasil uji sudut tenang menunjukan bahwa semakin besar kandungan lempung didapatkan nilai sudut tenang yang semakin besar, berbanding terbalik dengan tinggi jatuh penuangan, semakin tinggi jatuh penuangan membuat nilai sudut tenang yang semakin kecil (Listyawan AB, dkk, 2019). Abdul Hakam, dkk, 2010, menyimpulkan semakin besar kadar lempung yang ditambahkan kedalam pasir pantai maka semakin meningkat nilai kohesi tanah, dan sudut geser akan menjadi semakin menurun. Pasir pantai dapat digunakan sebagai bahan campuran beton aspal dengan kadar aspal optimum 5,32\% dengan nilai (stabilitas, flow, VITM, VMA, VFWA, MQ) memenuhi standar Bina Marga (Kusharto, H, 2004). Stabilisasi tanah pasir pantai Losari dengan menggunakan abu sampah (eco-cement) menunjukan terjadi peningkatan parameter kuat geser setelah pasir pantai dicampur dengan bahan eco-cement ( Idrus I, 2017).

\section{METODOLOGI}

Pada penelitian ini sebagai sampel uji adalah tanah pasir pantai yang diambil didaerah Pasir Jambak Tabing Padang, dan tanah lempung sebagai bahan pencampur diperoleh dari Palapa Batang Anai Pariaman. Pengujian sampel dilakukan di-Laboratorium Teknik Sipil Institut Teknologi Padang, komposisi tanah lempung terhadap tanah pasir pantai adalah $0 \%, 15 \%, 30 \%$ dan $45 \%$ terhadap berat kering pasir pantai, pengujian terdiri dari uji sifat fisis dan uji sifat mekanis dari pasir pantai maupun pasir pantai yang telah dicampur dengan berbagai variasi persentase tanah lempung dengan kondisi tanah dalam keadaan terganggu (disturbed). Adapun uji sifat fisis mencakup uji kadar air, spesific gravity, batas cair ( $L L)$, uji saringan dan hidrometer, dan uji sifat mekanis terdiri dari uji pemadatan, Uji CBR laboratorium terendam (soaked) maupun tidak terendam (unsoaked). Peralatan yang digunakan dalam penelitian ini antara lain ;

1) satu set saringan standar ASTM D42158 dan hidrometer ASTM D422-63

2) satu set alat ukur gravitas khusus ASTM D8554-58

3) alat uji batas konsistensi ASTM D42366, D424-59 dan D427-61

4) alat pemadat standar ASTM D698-78

5) satu set alat uji $C B R$ mengacu $A S T M$ D1883-16

6) alat-alat bantu yang terdiri dari oven, timbangan dengan ketelitian 0,01, stop watch, termometer, gelas ukur 1000 $\mathrm{ml}$, desicator, cawan, picnometer.

Pengujian dimulai dengan uji pendahuluan terdiri dari pemeriksaan sifat fisis tanah pasir pantai, tanah lempung dan dilanjutkan dengan uji sifat mekanis dari tanah pasir pantai. Selanjutnya dilakukan pengujian utama yang terdiri dari uji sifat fisis dan uji sifat mekanis dari pasir pantai yang telah dicampur dengan berbagai variasi persentase tanah lempung. Adapun urutan dari pengujian tersebut dapat dilihat pada Bagan Alir Penelitian (Gambar 1). 


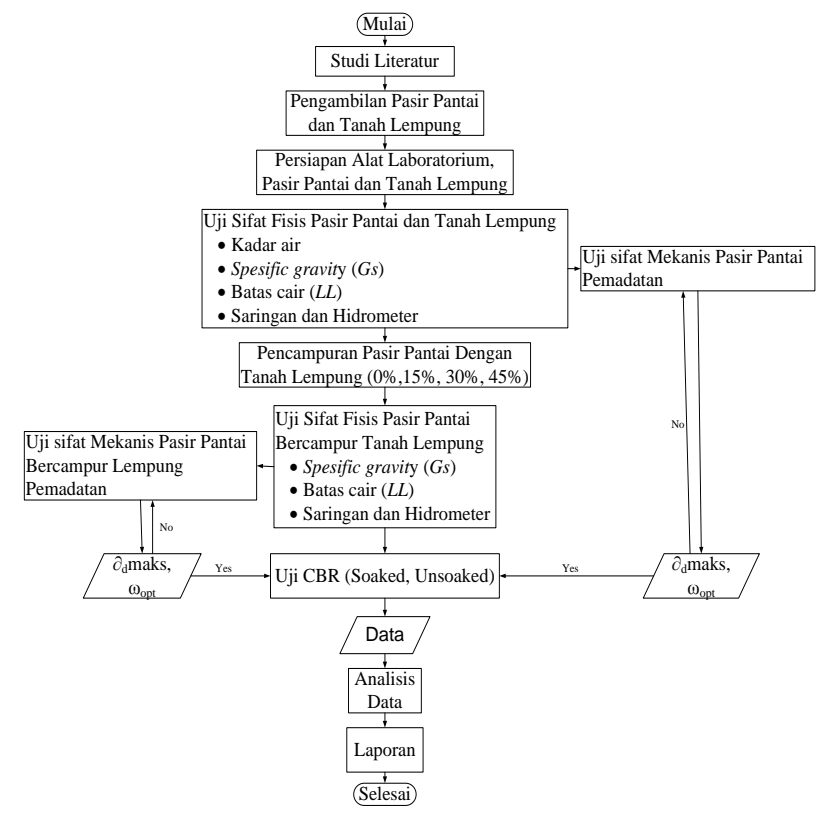

Gambar 1. Bagan Alir Penelitian

\section{HASIL PENGUJIAN DAN \\ PEMBAHASAN}

Hasil pengujian pendahuluan

Hasil pengujian pendahuluan terdiri dari hasil pengujian sifat fisis pasir pantai (Tabel 1), sifat fisis tanah lempung (Tabel 2) dan sifat mekanis pasir pantai (Tabel 3).

Tabel 1 Hasil Pengujian Sifat Fisis Pasir Pantai

\begin{tabular}{|c|l|c|}
\hline No. & \multicolumn{1}{|c|}{ Jenis Pengujian } & Hasil \\
\hline 1 & Gravitas Khusus $(G s)$ & 2,67 \\
2 & Lolos Saringan no.4 & $100 \%$ \\
3 & Lolos Saringan no. 10 & $99,72 \%$ \\
4 & Lolos Saringan no. 40 & $62,42 \%$ \\
5 & Lolos Saringan no. & $1,05 \%$ \\
6 & $200 \quad$ & $98,95 \%$ \\
7 & Tertahan Saringan no. & $0,16 \mathrm{~mm}$ \\
8 & 200 & $0,29 \mathrm{~mm}$ \\
9 & $\mathrm{D}_{10}$ & $0,41 \mathrm{~mm}$ \\
10 & $\mathrm{D}_{30}$ & 2,56 \\
11 & $\mathrm{D}_{60}$ & 1,28 \\
12 & $\mathrm{C}_{\mathrm{u}}$ & Buruk \\
13 & $\mathrm{C}_{\mathrm{c}}$ & Seragam) \\
& $\mathrm{Gradasi}$ & $0,00 \%$ \\
& Batas cair $(L L)$ & \\
\hline
\end{tabular}

Tabel 2 Hasil Uji Sifat Fisis Tanah Lempung

\begin{tabular}{|c|l|c|}
\hline No. & \multicolumn{1}{|c|}{ Jenis Pengujian } & Hasil \\
\hline 1 & Gravitas Khusus $(G s)$ & 2,65 \\
2 & Batas Cair $(L L)$ & $68,54 \%$ \\
\hline
\end{tabular}

\begin{tabular}{|l|l|l|}
\hline 3 & Batas Plastis $(P L)$ & $42,32 \%$ \\
4 & Indeks Plastis $(P I)$ & $26,22 \%$ \\
5 & Lolos Saringan no. 200 & $76,70 \%$ \\
6 & Tertahan Saringan no. & $23,30 \%$ \\
& 200 & \\
\hline
\end{tabular}

Tabel 3 Hasil Pengujian Sifat Mekanis Pasir Pantai

\begin{tabular}{|c|l|c|}
\hline No. & \multicolumn{1}{|c|}{ Jenis Pengujian } & Hasil \\
\hline 1 & Berat volume kering & 1,20 \\
2 & maksimum (Jdmaks) & gr/cm \\
3 & Kadar Air Optimum ( $\mathrm{w}_{\text {opt }}$ ) & $13,11 \%$ \\
4 & CBR (Soaked) & $7,82 \%$ \\
5 & Pengembangan & $0,00 \%$ \\
& CBR (Unsoaked) & $16,40 \%$ \\
\hline
\end{tabular}

\section{1.b Hasil pengujian utama}

Pengujian utama terdiri dari uji sifat fisis dan sifat mekanis pasir pantai yang telah dicampur dengan berbagai variasi persentase tanah lempung, hasil dari pengujian tersebut seperti Tabel 4 dan Tabel 5.

Tabel 4 Hasil Uji Sifat Fisis Pasir Pantai Yang Telah Dicampur Dengan Tanah Lempung

\begin{tabular}{|c|l|c|c|c|}
\hline \multirow{2}{*}{ No } & \multirow{2}{*}{$\begin{array}{c}\text { Jenis } \\
\text { Pengujian }\end{array}$} & \multicolumn{3}{|c|}{ Persentase Tanah Lempung } \\
\cline { 3 - 5 } & Gs & 2,67 & $30 \%$ & $45 \%$ \\
\hline 2 & $L L$ & $17,14 \%$ & 19,67 & 2,67 \\
3 & Lolos no. & $14,19 \%$ & 23,71 & $\%$ \\
4 & 200 & $85,81 \%$ & $\%$ & 37,34 \\
5 & Tertahan no. & 0,059 & 76,11 & $\%$ \\
6 & 200 & $\mathrm{~mm}$ & $\%$ & 62,66 \\
7 & $\mathrm{D}_{10}$ & 0,29 & 0,039 & $\%$ \\
8 & $\mathrm{D}_{30}$ & $\mathrm{~mm}$ & $\mathrm{~mm}$ & 0,04 \\
9 & $\mathrm{D}_{60}$ & 0,50 & 0,18 & $\mathrm{~mm}$ \\
10 & $\mathrm{C}_{\mathrm{u}}$ & $\mathrm{mm}$ & $\mathrm{mm}$ & 0,06 \\
& $\mathrm{C}_{\mathrm{c}}$ & 8,47 & 0,49 & $\mathrm{~mm}$ \\
& $\mathrm{Gradasi}$ & 2,85 & $\mathrm{~mm}$ & 0,32 \\
& & Sangat & 12,56 & $\mathrm{~mm}$ \\
& & Baik & 1,70 & 8,00 \\
& & & Sangat & 0,28 \\
& & & Baik & Buruk \\
\hline
\end{tabular}

Tabel 5 Hasil Uji Sifat Mekanis Pasir Pantai Yang Telah Dicampur Dengan Tanah Lempung

\begin{tabular}{|c|c|c|c|c|}
\hline \multirow{2}{*}{ No } & Jenis & \multicolumn{3}{|c|}{ Persentase Tanah Lempung } \\
\cline { 3 - 5 } & Pengujian & $15 \%$ & $30 \%$ & $45 \%$ \\
\hline 1 & $\gamma_{\mathrm{d}}$ maks & 1,29 & 1,41 & 1,28 \\
\hline
\end{tabular}




\begin{tabular}{|l|l|c|c|c|}
\hline 2 & $\mathrm{~W}_{\text {opt }}$ & $\mathrm{gr} / \mathrm{cm}^{3}$ & $\mathrm{gr} / \mathrm{cm}^{3}$ & $\mathrm{gr} / \mathrm{cm}^{3}$ \\
3 & CBR & 14,01 & $15,00 \%$ & $15,50 \%$ \\
4 & (Soaked) & $\%$ & $20,88 \%$ & $16,33 \%$ \\
5 & Pengemban & $13,25 \%$ & $0,04 \%$ & $0,21 \%$ \\
& gan & $0,01 \%$ & $26,66 \%$ & $25,56 \%$ \\
& CBR & $17,53 \%$ & & \\
& (Unsoaked) & & & \\
\hline
\end{tabular}

\section{Pembahasan}

\section{a Pasir Pantai}

Butiran lolos saringan no. 200 adalah $1,05 \%<50 \%$ dan lolos saringan no. 4 adalah $100 \%>50 \%$, nilai Cc 1,28 dan $\mathrm{Cu} 2,56<6$, maka pasir pantai ini masuk dalam klasifikasi pasir bergradasi buruk (gradasi seragam) atau SP (USCS), dan A-3(0) menurut AASHTO, karena lolos saringan no. 40 sebesar $62,42 \%>50 \%$, dan masuk kedalam kelompok pasir halus, baik jika digunakan sebagai tanah dasar jalan raya. Tetapi pasir pantai dalam kondisi ini sulit dipadatkan dan mudah terhambur kembali.

b Karakteristik pasir pantai yang dicampur dengan tanah lempung

Tanah lempung dalam kandungan pasir dapat merubah sifat-sifat pasir pantai, baik sifat-sifat fisis maupun sifat-sifat mekanisnya, sifat-sifat fisis mencakup berat jenis atau specific gravity, lolos saringan no. 200, nilai batas cair $(L L)$ sedangkan sifat mekanis antara lain nilai kepadatan maksimum ( $\gamma_{d}$ maks), kadar air optimum $\left(w_{\text {opt }}\right), C B R$ baik terendam maupun tidak terendam dan pengembangan.

\section{Butiran Lolos Saringan no. 200}

Kandungan tanah lempung dalam pasir pantai dapat meningkatkan perentase butiran lolos saringan no. 200 dari pasir pantai (Gambar 2).

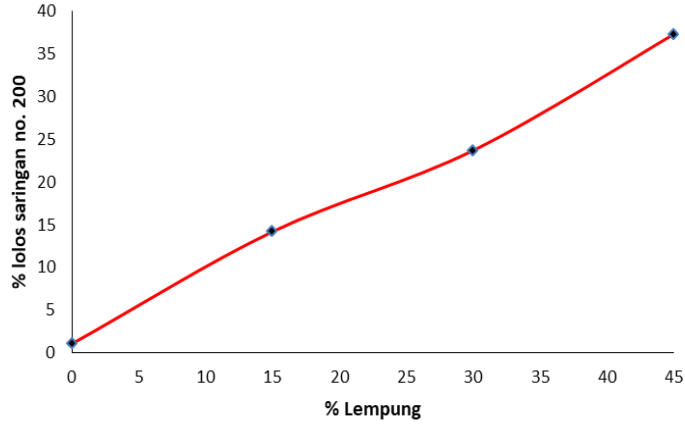

Gambar 2 Pengaruh tanah lempung terhadap butiran lolos saringan no. 200 dari pasir pantai

Gambar kurva menunjukan tejadi peningkatan butiran lolos saringan no. 200 seiring dengan meningkatnya persentase tanah lempung didalam pasir pantai, pada $45 \%$ tanah lempung didalam pasir pantai, persentase lolos saringan no. 200 adalah 37,34\%, jika dibandingkan dengan lolos saringan no. 200 pasir pantai asli yaitu $1,05 \%$ terjadi peningkatan sebesar $36,29 \%$ atau $3456,19 \%$ dari lolos saringan no. 200 pasir pantai asli. Peningkatan ini disebabkan karena tanah lempung yang dicampurkan kedalam pasir pantai mempunyai butiran lolos saringan no. 200 yang cukup besar yaitu $76,70 \%$ (Tabel 2).

\section{Specific Gravity (Gs)}

Keberadaan tanah lempung didalam pasir pantai tidak begitu mempengaruhi nilai specific gravity $(G s)$ dari pasir pantai (Gambar 3).

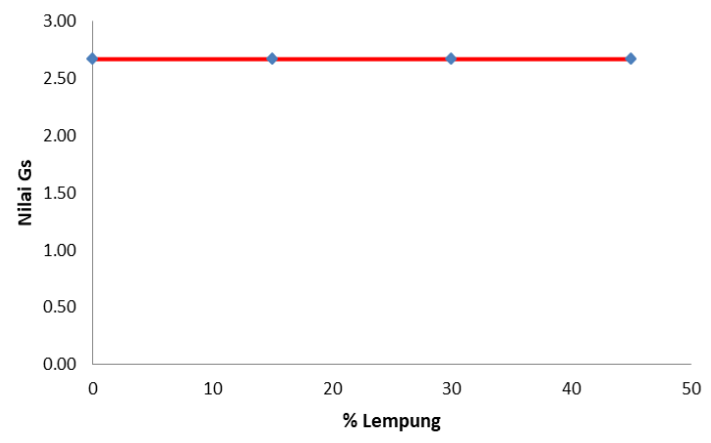

Gambar 3 Pengaruh tanah lempung terhadap nilai specific gravity pasir pantai 
Dari Gambar kurva terlihat garis yang cenderung mendatar, hal ini disebabkan karena nilai specific gravity pasir pantai dan tanah lempung yang besarannya hampir sama.

\section{Batas Cair $(L L)$}

Nilai batas cair meningkat seiring dengan bertambahnya persentase tanah lempung didalam kandungan pasir pantai (Gambar 4).

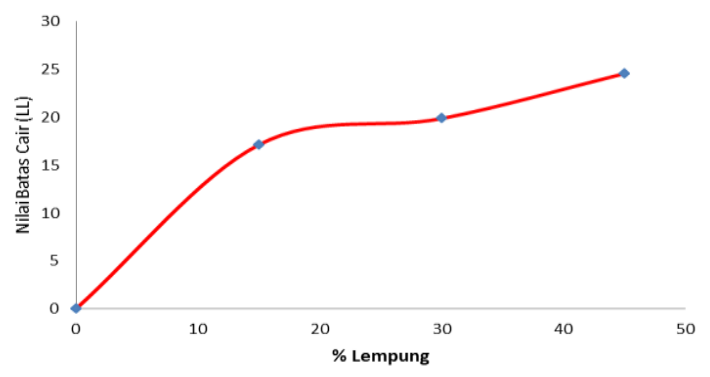

Gambar 4 Pengaruh tanah lempung terhadap nilai batas cair $(L L)$ pasir pantai

Pada kandungan $45 \%$ tanah lempung didalam pasir pantai, nilai batas cair dari pasir pantai yang dicampur dengan tanah lempung ( $L L) \quad 24,58 \%$, terjadi peningkatan sebesar 24,58\%. Karena nilai batas cair pasir pantai pada awalnya adalah 0 , Hal ini disebabkan karena tanah lempung sebagai bahan pencampur pasir pantai mempunyai nilai batas cair yang cukup besar yaitu sebesar $68,54 \%$.

\section{Pemadatan}

Uji pemadatan diadakan untuk mengetahui nilai kepadatan maksimum $\left(\gamma_{\mathrm{d}}\right.$ maks) dan nilai kadar air optimum $\left(\mathrm{w}_{\mathrm{opt}}\right)$, hasil uji pemadatan dari pasir pantai dan pasir pantai yang telah dicampur dengan berbagai variasi persentase tanah lempung seperti

\section{Gambar 5 dan Gambar 6}

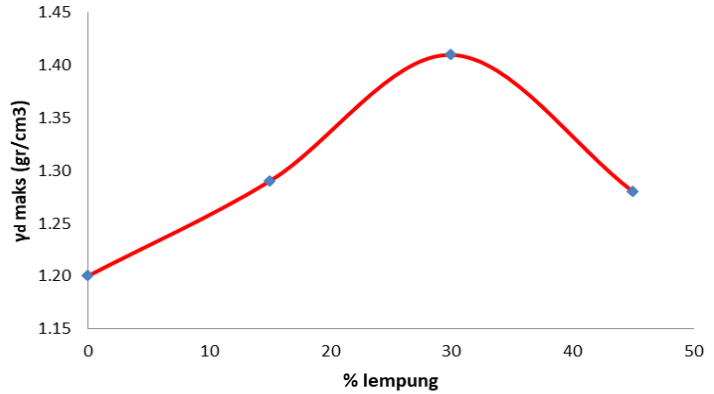

Gambar 5 Pengaruh tanah lempung terhadap nilai kepadatan $\left(\gamma_{d}\right.$ maks) pasir pantai

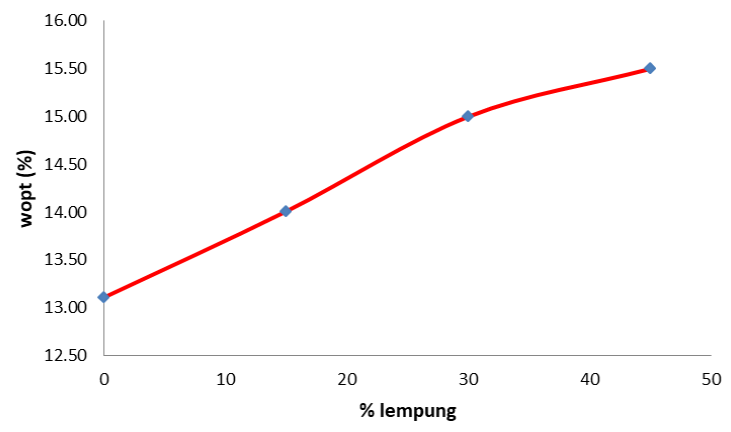

Gambar 6 Pengaruh tanah lempung terhadap nilai kadar air optimum $\left(w_{\text {opt }}\right)$ pasir pantai

dari gambar kurva terlihat nilai kepadatan pada awalnya meningkat, seiring dengan meningkatnya persentase lempung didalam kandungan pasir pantai, pada penambahan kadar lempung selanjutnya nilai kepadatan cenderung turun, pada kadar $30 \%$ tanah lempung dalam pasir pantai nilai kepadatan $\quad 1,41 \quad \mathrm{gr} / \mathrm{cm}^{3}, \quad$ jika dibandingkan dengan nilai kepadatan pasir pantai yang belum dicampur 1,20 gr. $\mathrm{cm}^{3}$, terjadi peningkatan sebesar 0,21 $\mathrm{gr} / \mathrm{cm}^{3}$ atau $17,5 \%$ dari nilai kepadatan pasir pantai asli. Mengacu kepada hasil uji analisis ukuran butir, pada pencampuran $30 \%$ kadar lempung didalam pasir pantai, diperoleh hasil uji dengan gradasi yang paling baik, akibatnya rongga yang terbentuk saat uji pemadatan lebih kecil jika dibandingkan dengan hasil uji pemadatan pada tanah pasir pantai asli maupun dengan pasir pantai yang telah dicampur tanah lempung dengan persentase campuran tanah lempung yang lain. Mengecilnya 
rongga pori kepadatan yang diperoleh semakin baik. Pada peningkatan kadar lempung selanjutnya, diperoleh gradasi yang buruk akibat meningkatnya butiran halus, disamping itu nilai kadar air optimum meningkat, pada $45 \%$ lempung didalam kandungan pasir pantai, kadar air optimum $15,50 \%$, jika dibandingkan dengan kadar air optimum pasir pantai sebelum dicampur 13,11\%, terjadi peningkatan sebesar 2,39\% atau 18,23\% dari nilai kadar air optimum pasir pantai sebelum pencampuran. Hal ini disebabkan karena tanah lempung membutuhkan banyak air dalam proses pencairannya, apalagi lempung yang digunakan sebagai bahan pencampur mempunyai nilai batas cair $(L L)$ yang cukup tinggi yaitu $68,54 \%$. Dengan meningkatnya kadar air optimum mengakibatkan terbentuknya ronggarongga yang diisi air, hal ini akan mereduksi kepadatan dari pasir pantai.

\section{CBR}

Pada uji $C B R$ diperoleh besaran-besaran antara lain nilai $C B R$ terendam (soaked) dan tidak terendam (unsoaked) serta nilai pengembangan, hasil uji $C B R$ terhadap pasir pantai asli dan pasir pantai yang telah dicampur dengan berbagai variasi persentase lempung seperti Gambar 7, Gambar 8 dan

\section{Gambar 9}

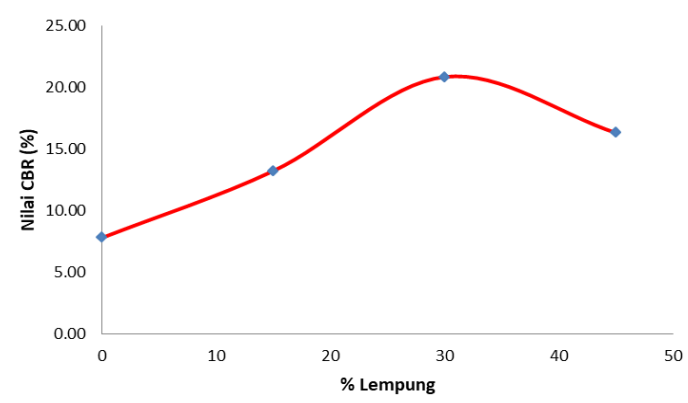

Gambar 7 Pengaruh tanah lempung terhadap nilai CBR pasir pantai dengan rendaman (Soaked)

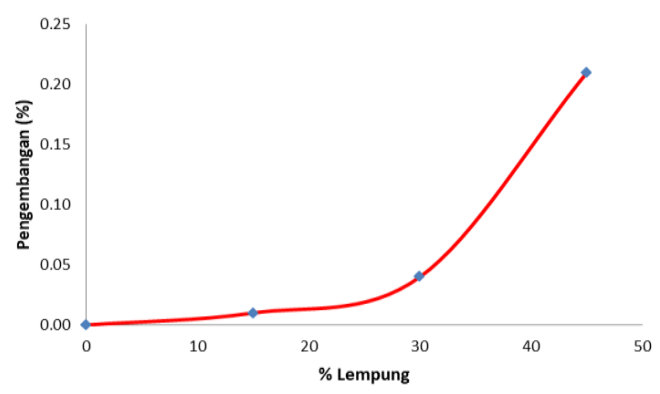

Gambar 8 Pengaruh tanah lempung terhadap nilai pengembangan pasir pantai

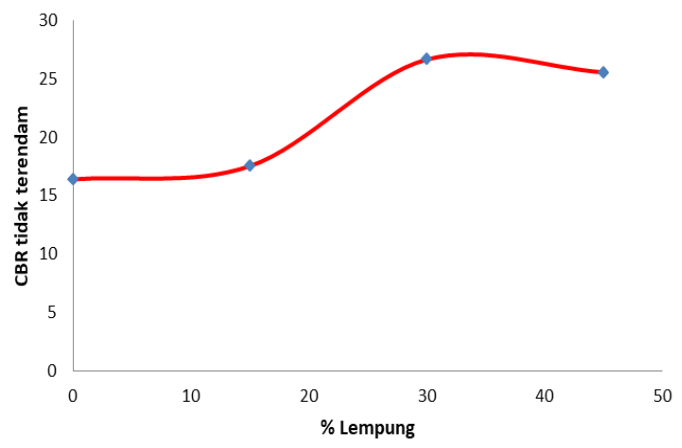

Gambar 9 Pengaruh tanah lempung terhadap nilai CBR pasir pantai tanpa rendaman (unsoaked)

Hasil uji $C B R$ baik dengan rendaman (soaked), maupun tanpa rendaman (unsoaked), pada awalnya nilai-nilai ini cenderung naik, seiring dengan meningkatnya persentase lempung didalam kandungan pasir pantai nilainilai $C B R$ ini mengalami penurunan. Pada pencampuran $30 \%$ tanah lempung terhadap pasir pantai, nilai $C B R$ dengan rendaman (soaked) 20,88\% dan tanpa rendaman (unsoaked) 26,66\%, jika dibandingkan dengan kondisi yang sama terhadap pasir pantai asli, nilai $C B R$ dengan rendaman (soaked) 7,82\%, tanpa rendaman (unsoaked) 16,40\%, maka untuk $C B R$ dengan rendaman (soaked) terjadi peningkatan sebesar $13,06 \%$ atau $167 \%$ dari nilai $C B R$ dengan rendaman (soaked) pasir pantai asli, dan CBR tanpa rendaman (unsoaked) meningkat sebesar $10,26 \%$ atau $62,56 \%$ dari nilai $C B R$ tanpa rendaman (unsoaked) pasir pantai asli. Meningkatnya nilai $C B R$ dengan rendaman (soaked) dan tanpa rendaman (unsoaked) akibat kepadatan 
tanah yang juga meningkat pada $30 \%$ kadar lempung dalam kandungan pasir pantai. Seiring dengan bertambahnya persentase lempung didalam kandungan pasir pantai, nikai CBR dengan rendaman (soaked) dan tanpa rendaman (unsoaked) menurun, hal ini disebabkan karena kepadatan tanah yang juga mengalami penurunan.

Sebaliknya nilai pengembangan terus meningkat seiring dengan meningkatnya persentase lempung didalam kandungan pasir pantai. Pada pencampuran $45 \%$ lempung didalam pasir pantai, nilai pengembangan $\quad 0,21 \%$. Terjadi peningkatan sebesar $0,21 \%$ karena pengembangan pasir pantai asli adalah 0\% (tidak mengembang). Meningkatnya nilai pengembangan ini sejalan dengan meningkatnya plastisitas tanah akibat pengaruh tanah lempung, hal itu dapat dilihat dari meningkatnya nilai batas cair $(L L)$ tanah.

Hasil terbaik pada penelitian ini diperoleh pada pencampuran 30\% tanah lempung terhadap pasir pantai, dimana pasir pantai yang telah dicampur dengan $30 \%$ lempung masuk klasifikasi $S W-S M$ (USCS) yaitu pasir dengan gradasi baik dan mengandung lanau atau $A-2-4(0)$ / $A$-2-6(0) (AASHTO) yaitu pasir berlanau dimana pasir kondisi ini baik digunakan sebagai tanah dasar (sub grade) jalan.

\section{PENUTUP}

Simpulan

Dari hasil analisa data yang telah dilakukan dapat disimpulkan bahwa keberadaan tanah lempung dalam campuran pasir pantai pada persentase yang tertentu dapat memperbaiki sifat fisis dan sifat mekanis dari pasir pantai, hasil terbaik diperoleh pada persentase $30 \%$ tanah lempung didalam kandungan pasir pantai dimana ;

a) Klasifikasi pasir pantai dari $S P$ meningkat ke $S W-S M$ (USCS), dan dari $A-3(0)$ berubah menjadi $A-2-4(0)$ / A-2-6(0)(AASHTO)

b) Gradasi pasir pantai yang seragam dan masuk kategori buruk, berubah menjadi gradasi yang sangat baik, sehingga baik digunakan sebagai bahan tanah dasar jalan atau sebagai material timbunan (urugan)

c) Nilai kepadatan meningkat $17,5 \%$ dari nilai kepadatan pasir pantai asli, begitu juga dengan daya dukungnya. Nilai CBR dengan rendaman (soaked) meningkat $167 \%$ dari nilai CBR dengan rendaman (soaked) pasir pantai asli, dan nilai $C B R$ tanpa rendaman (unsoaked) meningkat $62,56 \%$ dari nilai $C B R$ tanpa rendaman (unsoaked) pasir pantai asli.

\section{Saran}

Perlu penelitian yang lebih mendalam tentang pemanfaatan pasir pantai dalam menunjang pembangunan infrastruktur, terutama pada daerah-daerah dimana pasir sungai atau pasir untuk bahan bangunan sulit diperoleh

\section{DAFTAR PUSTAKA}

Anonim, 1992, Annual Book of ASTM Standarts, Section 4, Volume 04 08, Philadelphia,USA

Abdul Hakam, dkk, 2010 "Studi Pengaruh Penambahan Tanah Lempung Pada Tanah Pasir Pantai Terhadap Kekuatan Geser Tanah" Jurnal Rekayasa Sipil Volume 6 No. 1, Februari 2010

Hardiyatmo, H.C, 2012, Mekanika Tanah I dan II, Gadjah Mada University Press, Yogyakarta

Herman, dkk 2019 “Analisis Kerusakan Badan Jalan dan Alternatif Solusi (Studi Kasus Jalan Raya Lubuk Tarok - Taratak Baru Kabupaten Sijunjung)", Prosidding Seminar Nasional SPI-4 ITP, 10 Oktober 2019.

Idrus, I, 2017 "Stabilisasi Tanah Pasir Menggunakan Abu Sampah (EcoCement) Dan Uji Aplikasinya Terhadap Parameter Kuat Geser Tanah" ILTEX, Volume 12, Nomor 01, April 2017

Kusharto H, 2004 "Pengaruh Penggunaan Pasir Pantai Terhadap Sifat Marshall Dalam Campuran Beton Aspal" Media Komunikasi Teknik Sipil Volume 12 niomor 3 Edidi XXX Oktober 2004 
Listyawan AB, dkk, 2019 "Pengaruh Variasi Penambahan Lempung Pada Tanah

Pasir Terhadap Sudut Tenang" Simposium Nasional RAPI XVIII 2019 FT UMS hal 275 - 281

Muhammad RA. Simanjuntak, dkk, 2017 "Stabilisasi Tanah Lempung dengan campuran pasir pantai terhadap nilai CBR", Journal Of Civil Engineering, Building and Transportation (JCEBT), 1(2) September 2017 ; $96-104$. 